\title{
The Assessment of Socio-Psychological Effects of COVID-19 on Turkish People
}

\author{
By Burhanettin Uysal", Mehmet Yorulmaz, ${ }^{ \pm}$Mustafa Demirkıran ${ }^{+}$\& \\ Ebrar Ulusinan ${ }^{+}$
}

\begin{abstract}
In this study, it was aimed to measure the socio-psychological effects of the COVID-19 on Turkish people, and the scale was developed by the researchers. The study is limited between 24.03.2020 and 29.03.2020. The universe of the study, which included Turkey's population, is 15 year and older people. The study was carried out on 652 people. The data obtained from the questionnaires were investigated with SPSS (Statistical Package for Social Sciences) program and Lisrel. Mann-Whitney U, Kruskal-Wallis H test, and analysis of simple linear regression was performed. Confirmatory factor analysis (CFA) was applied with the Lisrel program. The validity $(K M O=0.867 / p=0.000)$ and reliability analysis $(\alpha=0.863)$ results of the scale are rather high. Looking to dimension scores, it was observed that the anxiety dimension had the highest score $(x=38.3 ;$ sd $=$ $7.29)$ and followed by the sociopolitical impact dimension $(x=18.7 ; s d=4.04)$. The lowest mean dimension is the psychosocial impact dimension $(\bar{x}=14.4$; $s d=5.48)$. According to the correlation analysis, it was a positively found relationship between anxiety and psychosocial impact, economic anxiety, and sociopolitical impact; a positive relationship between economic anxiety and sociopolitical effect with psychosocial impact; a positive relationship between economic anxiety and sociopolitical impact. The regression model established between all other dimensions was found significant ( $p<$ 0.05). It was found a significant difference between the dimensions of the scale with personal and occupational variables $(p<0.05)$.
\end{abstract}

Keywords: COVID-19, pandemic, perception, mental health, Turkey

\section{Introduction}

\section{Background}

Pandemics are one of the biggest disasters in which human beings have been desperate for centuries. People primarily lived together and established social relations after moving to the built-in layout. Human needs had in a way compelled people to live together. Therefore, individuals had in both social and physical interactions with their sexes. This interaction forced people to act responsibly towards each other. Particularly in pandemic diseases, that an individual living together in the community is sick, has become an important situation that concerns not only the individual but also all society. A social individual interacts with other people and the environment. The necessity of this interaction is that human beings act together against such great threats. Nowadays, while planning space travels,

\footnotetext{
*Assistant Professor, Bilecik Seyh Edebali University, Turkey.

${ }^{ \pm}$Assistant Professor, Selcuk University, Turkey.

${ }^{\sharp}$ Associate Professor, Isparta University of Applied Sciences, Turkey.

${ }^{+}$Research Assistant, Bilecik Seyh Edebali University, Turkey.
} 
when talking about the irradiation of matter, humankind is abruptly threatened by a killer virus that can only be seen under an electron microscope. In the short-term, the enemy of humankind is an invisible killer.

The World Health Organization (WHO) has defined the pandemic as "the emergence of a disease that mankind has never seen before, the spread of the disease among humans and the spread of the disease simply and constantly among humans" (Sirman 2020). In this context, it can be said that the COVID-19 is a pandemic, as it is accepted by the WHO.

The COVID-19, belonging to the coronavirus family, which emerged in Wuhan, China in December 2019 and causes a pandemic worldwide, occupies the first place on the world agenda. The COVID-19 has been one of the fastestgrowing coronavirus pandemics in the past two decades (Kagan et al. 2020). Large pandemics have occurred, by all means, in the world's history, but the COVID-19 has been more effective than the other known pandemic in terms of its spreading rate and the extent of its impact. In 8-9 months, it has caused negative results that will reach nearly to a halt in life in the world. The world, which has become a small village with globalization and has almost all borders disappeared, has been separated again and countries have had to retreat to their shells. It has occurred a pandemic affecting adversely almost all sectors, from the economy to tourism, from the health sector to the transportation sector.

\section{Important Pandemics in the History}

Some important pandemics in the world history have left their mark. Of these, although the Athens Outbreak (426-429 BC) is not the first known epidemic in history, it is known as the first pandemic, in which documents have proven the accuracy of which. Another one, Antoninus Pandemic (1665-180 BC), which is still known as smallpox, was a major epidemic that ravaged the Roman State. Justinianus Pandemic (541-750 BC), which is also known as the Black Death, was a pandemic that was the reason of death in most of Europe and Far East Asia. According to records, approximately 50 million people were dead because of the Black Death worldwide (Sirman 2020).

Spanish flu (1917-1918) is a major pandemic that is the reason dead of over 50 million people in about a year. The Camp Funston was a major pandemic that military infirmary was not enough and turned into an infirmary the hangar (Sirman 2020). This flu pandemic, which is also known as the flu of 1918, is one of the severest pandemics of recent history (Temel 2015). The cause of this pandemic is an $\mathrm{H} 1 \mathrm{~N} 1$ virus with bird-derived genes. Although there is no universal consensus on where the virus originated from, it is known that it swept the world from 19181919 (Centers for Disease Control and Prevention 2020a).

One of the biggest pandemics that humanity faced recently was Swine Flu (April 17, 2009). A new Influenza A (H1N1) type appeared in Mexico and the USA in March and April 2009. This unfamiliar type of virus has spread to many regions and countries in a quick time. It was accepted as a pandemic by the World Health Organization on June 11, 2009 (Şanlı 2010). 
Middle East Respiratory Syndrome coronavirus (MERS-CoV), which is another important epidemic, emerged on June 13, 2012, in Jeddah, Saudi Arabia. It was seen in a 60-year-old Saudi patient with a history of fever, cough, sputum, and shortness of breath (Zaki et al. 2012). As of December 2018, 2279 MERS cases were reported 806 deaths worldwide. Most of these cases (38.5\% case-mortality rate, with 1901 cases) were reported from Saudi Arabia. No significant difference or change was observed in terms of demographic and epidemiological characteristics of the cases between 2013 and 2018. The risky age group for secondary cases is 30-39. Considering the number of deaths, it is higher in the 5059 age group for primary cases and in the 70-79 age group for secondary cases (World Health Organization 2019).

It is necessary to look at the chronology of coronavirus pandemics that are also the subject of this study. Coronaviruses (2003-) consist of an extensive family. We see that the first outbreak is a pandemic that known in public as the SARS virus. SARS-Coronavirus, which causes severe acute respiratory failure, is a coronavirus first seen in China in February, 2003. Different groups of coronaviruses are available. These are group 1 and group 2 coronaviruses. It contains viruses that are mostly seen in mammals. SARS-CoV-2 virus is a subgroup of the coronavirus family that needs a host to live and reproduce (Yücel and Görmez 2019).

\section{The COVID-19 and Development Process}

The COVID-19, which has become a terrible problem all over the world, is spreading faster every day (Musinguzi and Asamoah 2020). On March 11, 2020, the WHO declared the COVID-19 as a pandemic. There is no proper treatment for the COVID-19 in Medical Science and the number of people affected is increasing every day (Majumder et al. 2020). As of September 6, 2020, over 26 million people worldwide were infected with SARS-CoV-2 virus, and nearly 900 thousand people have died because of the COVID-19. The number of cases in Turkey is around 300 thousand (World Health Organization 2020). From what we have seen around us, there is panic and fear in people. With the COVID-19, fear is triggered throughout the community and timely understanding of the psychological state of society becomes important (Xiang et al. 2020, Hall and Chapman 2008). But society's awareness of the disease could potentially reduce the size of the pandemic. At the same time, the awareness of people can slow the spread of the pandemic and lower the eventual incidence (Funk et al. 2009). The most important pillar of this awareness is social isolation. Social isolation means distancing or stopping interpersonal interaction to slow down a very contagious spread. Social isolation is to stay people, partially or completely, away from work, transportation and other activities that may increase social contact and spread. For example, in Wuhan City, where the pandemic first occurred, over 10 million people stayed in their homes and complied with social isolation measures (Musinguzi and Asamoah 2020). Transmission from one person to another is seriously rapid for the SARS-CoV-2 virus. This situation has caused panic in the society, so nearly all schools and colleges around the world have been closed and their social meetings 
have been canceled. Individuals should prevent the spread of the virus by constantly washing their hands again, using personal protective equipment (masks) to protect their health. Thus, they should reduce risk factors (Majumder et al. 2020).

If we talk about the socio-psychological effects of the COVID-19, everyone's reactions to stressful situations may be varied. How the person responds to the pandemic varies depending on his/her past, personal characteristics, and the society in which they live. Elderly people who have a higher risk for the COVID19 and those with chronic diseases, children and junior people, healthcare professionals, people with mental problems may feel more anxiety and concern in the situation. People experience intensive emotions during the pandemic process such as fear and anxiety, changes in sleep and eating, difficulty concentrating, increased use of alcohol, tobacco, or other medicines, frustration, financing concerns (Centers for Disease Control and Prevention 2020b, Brooks et al. 2020, De Roo et al. 1998).

The COVID-19 is also thought to affect the world, socio-economically. In particular, the decline in global demand for oil and natural gas has reduced government revenues and liquidity. International oil prices have reached the cheapest level in the COVID-19 process. At the same time, global and local closures cause declines in the tourism industry and retail industry and lower capital inflows for slow the spread of the virus. These trends interrupt both local and international economic development goals (Oxford Analytica 2020). In addition to economic effects, pandemic diseases (such as the flu) are seen as diseases that will be included in health systems in the future. Many healthcare organizations will need personnel protective equipment to control the pandemic virus (Nancy and Christopher 2007).

This study was conducted to test the psychological, sociological, and economic effects of the COVID-19 on individuals and to develop an original scale in this context. With this study, it was thought to investigate and reduce some socio-psychological negative effects for people in the process of the COVID-19.

\section{Materials and Methods}

\section{The Design of the Research}

Quantitative data design was used in the study. In this context, a scale was developed by the researchers.

\section{The Universe and the Sample of the Research}

The universe of the study is composed of people included in the population of Turkey, who are 15 age and older. According to the Turkish Statistical Institute (2019), there are 63.9 million people in the specified age range. Since the legislation (Turkish Labor Law No. 4857, Regulation on the Principles and Procedures for the Employment of Children and Young Persons) defines the 15-18 
age group as a young worker, the lower age limit of the sampling was determined to be 15 age. Since the universe contains many people, it is impossible to reach the entire of the universe in the study due to reasons such as cost and time limit, so it was preferred to choose a sample from the universe. When the literature is analyzed, it is seen that a sample of 384 people represents a population between $1,000,000-100,000,000$ people with a $95 \%$ confidence interval and $5 \%$ error margin (Yazıcıŏlu and Erdoğan 2004).

\section{Data Collection}

To collect data related to the study, the questionnaire method was preferred. The questionnaire used comprises three parts. In the first section, there are 10 questions to determine the personal and professional characteristics of the participants. In the second part of the questionnaire, there are five general questions about the COVID-19. In the last part, there is the COVID-19 Impact Assessment Scale that developed by researchers, comprising 40 items and prepared in a 5-point Likert type ( $1=$ Never agree, $5=$ I totally agree $)$.

The COVID-19 Impact Assessment Scale, which consisted of 76 items after literature review, was sent to two academicians and two teachers who were experts in the field before the final form was given, and after some statements were removed and some statements were corrected, the scale became final. The data collection tool created was delivered to the participants using the online survey method and filled in by the participants. The total number of participants surveyed is 670 . After the extremes on the scale were removed, the final number of surveys on the scale was 652 .

\section{Analysis of Data}

Two statistical programs were used in the analysis of data. SPSS 22.0 program was used for exploratory factor analysis (EFA), basic and advanced analysis. Non-parametric test techniques were used in the analysis since the data did not show normal distribution. The Mann-Whitney $U$ test was used for binary comparisons and the Kruskal-Wallis $\mathrm{H}$ test was used for comparisons in over two groups. The relationship between dimensions was analyzed by the Spearman correlation test. Simple linear regression analysis was performed to examine the direction and effect of the relationship between dimensions. Lisrel 8.80 program was used for confirmatory factor analysis (CFA).

KMO (Kaiser Mayer Olkin) to test the adequacy of the sample size to determine the suitability of the scale for factor analysis; Bartlett's sphericity test was performed to measure whether the data got the multivariate normal distribution. These test results are given in Table 1. 
Table 1. Validity and Reliability Tests of the Scale

\begin{tabular}{|c|c|c|c|c|}
\hline \multicolumn{2}{|c|}{ KMO and Bartlett's Test } & Reliability Statistics \\
\hline \multirow{2}{*}{ Kaiser-Meyer-Olkin Measure of Sampling Adequacy } & 0.849 & $\begin{array}{c}\text { Cronbach's } \\
\text { Alpha }\end{array}$ & $\begin{array}{c}\text { N of } \\
\text { Items }\end{array}$ \\
\hline \multirow{2}{*}{ Bartlett's Test of Sphericity } & Approx. Chi-Square & $4,466.774$ & \multirow{2}{*}{0.891} & 4 \\
\cline { 2 - 3 } & df & 780 & 0.000 & \\
\cline { 2 - 3 } & Sig. & 00.000 & \\
\hline
\end{tabular}

Firstly, the scale prepared was implemented on 24.03 .2020 by a web-based source, and validity and reliability analysis was performed with data obtained after approximately six hours. Accordingly, the overall scale of Cronbach's alpha value was 0.891 ; KMO value 0.849 , p < 0.000; df 780 and Bartlett sphericity test were found at 4,466.774 and the questionnaire was ended on 29.03.2020 as the results of validity and reliability analysis were acceptable (Karakoç and Dönmez 2014, Field 2002).

The construct validity of the scale was analyzed according to EFA and scree plot values (Figure 1) with data obtained from 652 samples. In this analysis were used expressions greater than 0.40 and Eigenvalue above of 1 for factor loads using the Principal component with Extraction method, and the varimax as the rotation method.

Figure 1. Scree Plot Chart for Scale

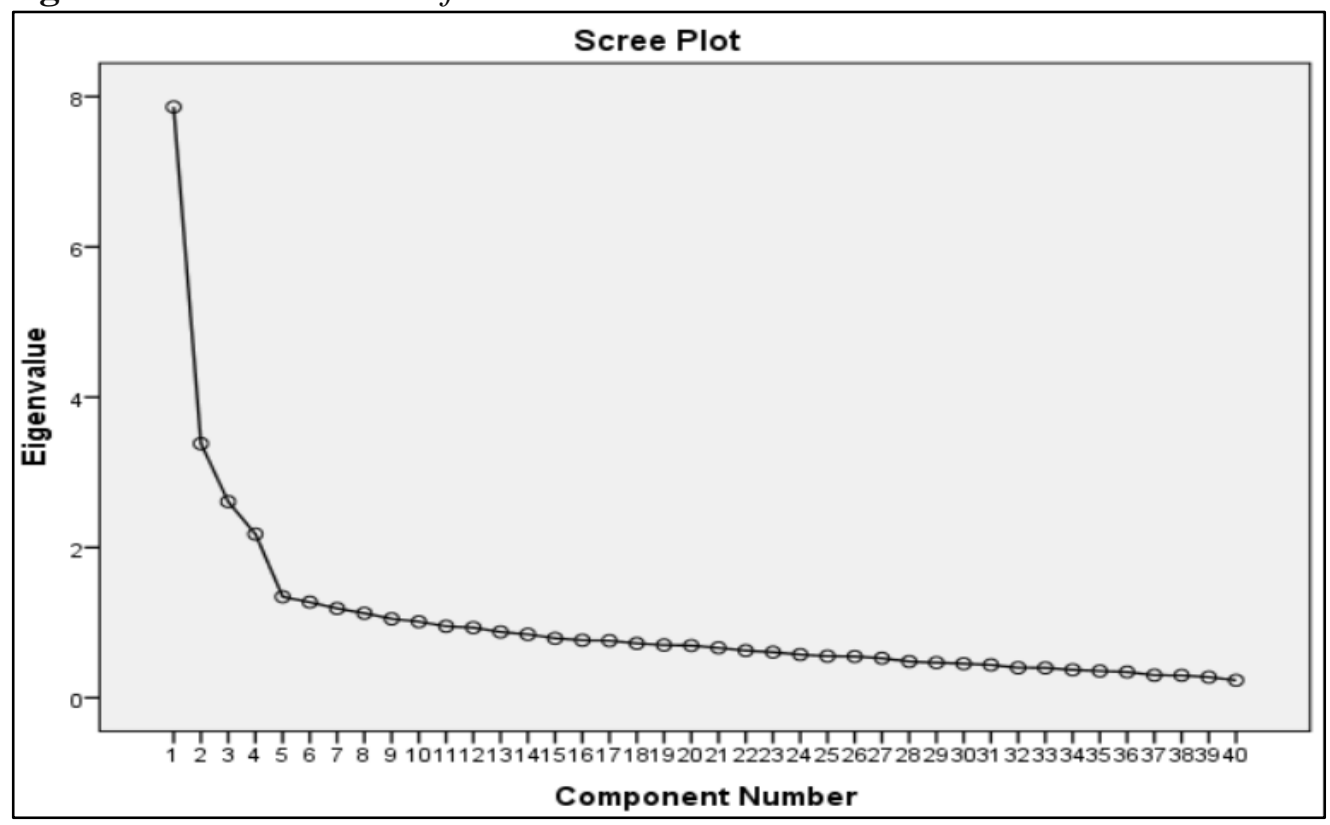

As shown in Table 2, factor loads vary between 0.427 and 0.760 and consist of five factors and 31 expressions. Scale factors were constructed over the total scores of the items. Expressions 1, 5, 7, 13, 20, 24, 28, 30, and 38 were removed from the draft scale after factor analysis. 
Table 2. Results of Exploratory Factor Analysis

\begin{tabular}{|c|c|c|c|c|c|c|}
\hline \multirow{3}{*}{ Dimension } & \multicolumn{6}{|c|}{ Rotated Component Matrix ${ }^{\mathrm{a}}$} \\
\hline & \multirow{2}{*}{$\begin{array}{c}\text { Expression } \\
\text { No }\end{array}$} & \multicolumn{5}{|c|}{ Component } \\
\hline & & 1 & 2 & 3 & 4 & 5 \\
\hline \multirow{10}{*}{ 1. Anxiety } & 11 & 0.760 & & & & \\
\hline & 12 & 0.721 & & & & \\
\hline & 3 & 0.694 & & & & \\
\hline & 9 & 0.681 & & & & \\
\hline & 10 & 0.635 & & & & \\
\hline & 35 & 0.586 & & & & \\
\hline & 19 & 0.478 & & & & \\
\hline & 6 & 0.438 & & & & \\
\hline & 2 & 0.437 & & & & \\
\hline & 18 & 0.435 & & & & \\
\hline \multirow{6}{*}{ 2. Psychosocial Impact } & 8 & & 0.738 & & & \\
\hline & 15 & & 0.714 & & & \\
\hline & 4 & & 0.614 & & & \\
\hline & 17 & & 0.610 & & & \\
\hline & 14 & & 0.609 & & & \\
\hline & 16 & & 0.530 & & & \\
\hline \multirow{5}{*}{ 3. Perceived Confidence } & 40 & & & 0.779 & & \\
\hline & 22 & & & 0.764 & & \\
\hline & 29 & & & 0.740 & & \\
\hline & 23 & & & 0.697 & & \\
\hline & 25 & & & 0.629 & & \\
\hline \multirow{4}{*}{ 4. Economic Anxiety } & 31 & & & & 0.750 & \\
\hline & 33 & & & & 0.736 & \\
\hline & 34 & & & & 0.683 & \\
\hline & 32 & & & & 0.570 & \\
\hline \multirow{6}{*}{ 5. Sociopolitical Impact } & 21 & & & & & 0.586 \\
\hline & 26 & & & & & 0.580 \\
\hline & 37 & & & & & 0.527 \\
\hline & 27 & & & & & 0.496 \\
\hline & 36 & & & & & 0.466 \\
\hline & 39 & & & & & 0.427 \\
\hline
\end{tabular}

CFA is a type of analysis performed to test whether the structures (dimensions) in the scale show similarity according to EFA result in scale development studies, as it was done to test the similarity of the structures revealed in a previous study (Karagöz 2016). In CFA, hypotheses in a certain factor structure can be tested. Contrary to EFA, it does not calculate factor loads of expressions on the scale. It brings out the goodness-of-fit for the evaluation of the research model (Albright and Park 2009).

CFA was performed for the scale, which was evaluated by EFA and obtained in 5 dimensions, and it was tested whether the model was compatible. The uncovered model is shown in Figure 2. The figure presents a path diagram showing the causal change of variables for the model over other variables. The $t$ values are shown in the results of the first road analysis. 
Figure 2. Path Diagram

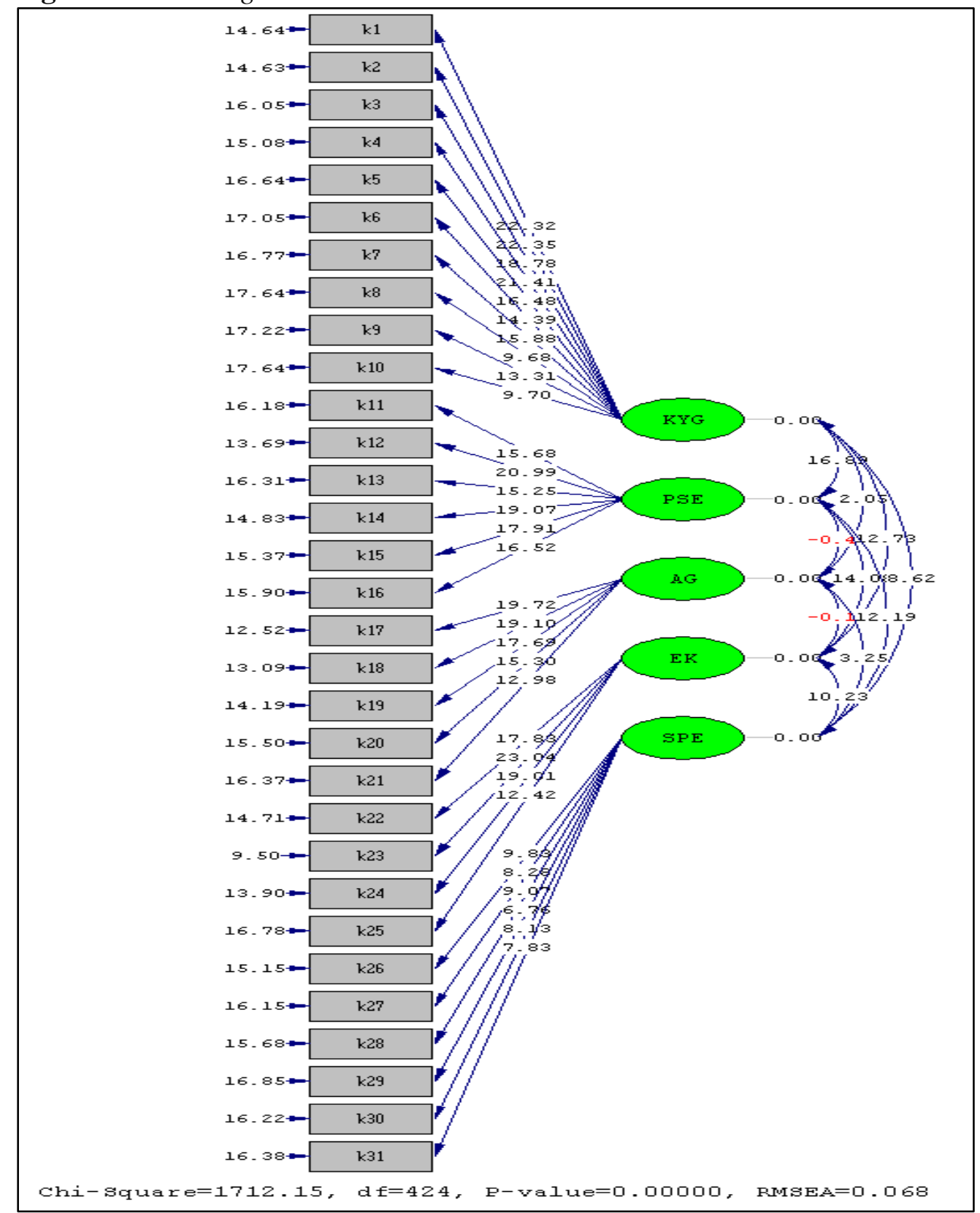

The values generally considered in the fit model are $\chi^{2} / \mathrm{DF}$, GFI, CFI, and RMSEA. According to the information in Table 3 , the value of $\chi^{2} / \mathrm{df}$ is an acceptable fit to be below 5, the GFI value is 0.85, it is again acceptable, the CFI value is close to acceptable compliance to be 0.93 , and RMSEA value is acceptable to be 0.068 . Within the framework of the obtained fit indices, it was revealed that the model has an acceptable fit (Karagöz 2016). 
Table 3. Estimates of Goodness-of-Fit Index for Model

\begin{tabular}{|l|c|c|c|c|}
\hline $\begin{array}{l}\text { The Criterion } \\
\text { of Model Fit }\end{array}$ & Good Fit & Acceptable Fit & $\begin{array}{c}\text { Fit in This } \\
\text { Study }\end{array}$ & Fit \\
\hline CMIN/SD & $\chi^{2} / \mathrm{sd} \leq 3$ & $\chi^{2} / \mathrm{sd} \leq 5$ & 3.6 & Acceptable \\
\hline $\begin{array}{l}\text { Chi-square Fit } \\
\text { Test }\left(\chi^{2}\right) \\
(\mathrm{p}=0.000)\end{array}$ & $0.05<\mathrm{p} \leq 1$ & $0.01<\mathrm{p} \leq 0.05$ & 0.000 & Acceptable \\
\hline RMSEA & RMSEA $\leq 0.05$ & RMSEA $\leq 0.08$ & 0.068 & Acceptable \\
\hline NFI & $0.95 \leq \mathrm{NFI}$ & $0.90 \leq \mathrm{NFI}$ & 0.90 & Acceptable \\
\hline NNFI & $0.95 \leq \mathrm{NNFI}$ & $0.90 \leq \mathrm{NNFI}$ & 0.92 & Acceptable \\
\hline CFI & $0.97 \leq \mathrm{CFI}$ & $0.95 \leq \mathrm{CFI}$ & 0.93 & Unacceptable \\
\hline IFI & $0.95 \leq \mathrm{IFI}$ & $0.90 \leq \mathrm{IFI}$ & 0.93 & Acceptable \\
\hline RMR & $0<\mathrm{RMR} \leq 0.05$ & $0<\mathrm{RMR} \leq 0.08$ & 0.094 & Unacceptable \\
\hline SRMR & $0<$ SRMR $\leq 0.05$ & $0<$ SRMR $\leq 0.08$ & 0.069 & Acceptable \\
\hline GFI & $0.90 \leq \mathrm{GFI}$ & $0.85 \leq \mathrm{GFI}$ & 0.85 & Acceptable \\
\hline AGFI & $0.90 \leq \mathrm{AGFI}$ & $0.85 \leq \mathrm{AGFI}$ & 0.83 & Unacceptable \\
\hline
\end{tabular}

Source: Karagöz 2016.

\section{Results}

In this chapter, findings related to the personal and professional characteristics of the participants, the general questions about the COVID-19, and the basic and advanced analysis results regarding the dimensions/variables of the research were examined.

Table 4 presents the findings regarding the personal and professional characteristics of the participants. Accordingly, the majority of the participants $(59.0 \%)$ are in the 18 to 25 age range. The proportion of female participants $(67.3 \%)$ is significantly higher than the proportion of male participants $(32.7 \%)$. The participation of singles $(73.0 \%)$ is considerably higher than married people $(27.0 \%)$. The highest participation in terms of education is among those with an associate degree (44.3\%). The ratio of those employed in any job (39.4\%) and students $(40.3 \%)$ is very close to each other. Among the participants, the proportion of those with a monthly income status of $1250 \mathrm{TL}$ and below is higher.

According to the findings of the general questions about the COVID-19, information about the COVID-19 is obtained from TV and internet news sites at the most. The majority of participants $(64 \%)$ think that the process of combating the COVID-19 is better managed in Turkey than in other countries. Based on this information, it can be said that the policies implemented by the government in the pandemic are effective and solution-oriented. Only $8 \%$ of the participants have a chronic disease and only $2.5 \%$ of them have been diagnosed COVID-19 to themselves or acquaintances. Close to half of the participants (44.9\%) believe that the progression of the COVID-19 will be under control within a time frame of 1 to 3 months. Looking at the point reached, it cannot be said that the pandemic can be fully controlled (Table 5). 
Table 4. Findings related to the Personal and Professional Characteristics of the Participants

\begin{tabular}{|c|c|c|c|c|c|c|c|c|c|c|c|c|c|c|}
\hline $\begin{array}{l}\text { Age } \\
\text { Range }\end{array}$ & $\%$ & $\mathbf{N}$ & Gender & $\%$ & $\mathbf{N}$ & $\begin{array}{c}\text { Education } \\
\text { Status }\end{array}$ & $\%$ & $\mathbf{N}$ & $\begin{array}{c}\text { Employment } \\
\text { Status }\end{array}$ & $\%$ & $\mathbf{N}$ & $\begin{array}{c}\text { Monthly } \\
\text { Income } \\
\text { Status } \\
\text { (TL) }\end{array}$ & $\%$ & $\mathbf{N}$ \\
\hline $15-17$ & 1.1 & 7 & \multirow{2}{*}{ Female } & \multirow{2}{*}{67.3} & \multirow{2}{*}{439} & $\begin{array}{c}\text { Primary } \\
\text { Education }\end{array}$ & 0.8 & 5 & Working & 39.4 & 257 & $1-1250$ & 45.9 & 299 \\
\hline $18-25$ & 59.0 & 385 & & & & \begin{tabular}{|l|} 
Secondary \\
Education
\end{tabular} & 7.4 & 48 & Retired & 0.5 & 3 & $1251-2325$ & 10.6 & 69 \\
\hline $26-35$ & 24.1 & 157 & \multirow[b]{2}{*}{ Male } & \multirow[b]{2}{*}{32.7} & \multirow[b]{2}{*}{213} & $\begin{array}{l}\text { Associate } \\
\text { Degree }\end{array}$ & 44.3 & 289 & Unemployed & 16.6 & 108 & $2326-3500$ & 12.3 & 80 \\
\hline $36-45$ & 12.7 & 83 & & & & $\begin{array}{c}\text { Bachelor } \\
\text { Degree }\end{array}$ & 35.1 & 229 & Another & 1.1 & 7 & $3501-5000$ & 15.2 & 99 \\
\hline $46-55$ & 2.3 & 15 & $\begin{array}{c}\text { Marital } \\
\text { Status }\end{array}$ & $\%$ & $\mathbf{N}$ & $\begin{array}{l}\text { Master's } \\
\text { Degree }\end{array}$ & 6.0 & 39 & Students & 40.3 & 263 & $5001-7000$ & 10.0 & 65 \\
\hline $56-65$ & 0.5 & 3 & Married & 27.0 & 176 & \multirow{2}{*}{$\begin{array}{l}\text { Doctor's } \\
\text { Degree }\end{array}$} & \multirow[b]{2}{*}{6.4} & \multirow[b]{2}{*}{42} & Housewife & 1.5 & 10 & \multirow{2}{*}{$\begin{array}{c}7001 \text { and } \\
\text { over }\end{array}$} & \multirow[b]{2}{*}{6.1} & \multirow[b]{2}{*}{40} \\
\hline $\begin{array}{l}66 \text { and } \\
\text { over }\end{array}$ & 0.3 & 2 & Single & 73.0 & 476 & & & & Freelancer & 0.6 & 4 & & & \\
\hline
\end{tabular}

Table 5. Findings related to General Questions about the COVID-19

\begin{tabular}{|l|c|c|l|c|c|}
\hline $\begin{array}{c}\text { What Resources do you Use Most When } \\
\text { Learning About the COVID-19? }\end{array}$ & \multicolumn{3}{c|}{ Do you Have Any Chronic Disease? } \\
\hline & $\%$ & $\mathrm{~N}$ & & $\%$ & $\mathrm{~N}$ \\
\hline TV & 66.4 & 433 & Yes & 8 & 52 \\
\hline Internet News Sites & 47.4 & 309 & No & 85.6 & 558 \\
\hline Instagram & 37.3 & 243 & I Have No Information & 6.4 & 42 \\
\hline Twitter & 35.7 & 233 & Have You or an Acquaintance Been Diagnosed \\
With COVIID-19?
\end{tabular}

Table 6 contains the findings regarding the basic and advanced analysis results for the dimensions/variables of the research. According to the findings; there is a moderate relationship between anxiety and psychosocial impact; weak relationship between anxiety and economic anxiety and sociopolitical impact; moderate relationship between psychosocial impact and economic anxiety; a weak relationship between psychosocial effect and sociopolitical effect; weak relationship between economic anxiety and sociopolitical impact.

When we look at the results of simple linear regression analysis between dimensions, the regression model established between the anxiety dimension and all other dimensions was found to be significant. 
The value of factor load was taken as 0.40 for factor analysis. Accordingly, nine statements in the draft scale were eliminated. The scale was determined to be very good with a KMO value of 0.867 and explaining $47.298 \%$ of the total variance. Cronbach's Alpha $(\alpha)$ coefficient, which determines the level of reliability, was found to be very good with 0.863 , and according to these results, it is seen that the scale has an adequate level of reliability.

The highest score that can be collected in the sub-dimensions of the scale is 50 , and the lowest score is 4 . The lowest score that can be collected in the total dimension is 31 , and the highest score is 155 . Calculations for the mean were according to the total scores. According to this information, it was observed that the anxiety dimension had the highest score $(\mathrm{x}=38.3$; $\mathrm{sd}=7.29)$, and followed by the sociopolitical impact dimension $(\mathrm{x}=18.7$; $\mathrm{sd}=4.04)$. The lowest mean dimension is the psychosocial impact dimension $(\overline{\mathrm{x}}=14.4$; $\mathrm{sd}=5.48)$.

Table 6. Findings related to the Basic and Advanced Analysis Results for the Dimensions/Variables of the Study

\begin{tabular}{|c|c|c|c|c|c|c|}
\hline No & $\begin{array}{c}\text { COVID-19 } \\
\text { Impact } \\
\text { Assessment Scale } \\
\text { Dimensions }\end{array}$ & 1 & 2 & 3 & 4 & 5 \\
\hline 1 & Anxiety & 1 & $\begin{array}{c}R^{2}=0.256 \\
p=0.000\end{array}$ & $\begin{array}{c}R^{2}=0.012 \\
p=0.004\end{array}$ & $\begin{array}{l}R^{2}=0.17 \\
p=0.000\end{array}$ & $\begin{array}{l}R^{2}=0.10 \\
p=0.000\end{array}$ \\
\hline 2 & $\begin{array}{c}\text { Psychosocial } \\
\text { Impact }\end{array}$ & $r=0.485^{* *}$ & 1 & $\begin{array}{l}R^{2}=0.000 \\
p=0.893\end{array}$ & $\begin{array}{l}R^{2}=0.19 \\
p=0.000\end{array}$ & $\begin{array}{l}\mathrm{R}^{2}=0.15 \\
\mathrm{p}=0.000\end{array}$ \\
\hline 3 & $\begin{array}{l}\text { Perceived } \\
\text { Confidence }\end{array}$ & $\mathrm{r}=0.076$ & $r=-0.041$ & $\mathrm{P} \quad \mathrm{s}=0 \mathrm{~s}$ & $\begin{array}{c}\mathrm{R}^{2}= \\
0.000 \\
\mathrm{p}=0.808\end{array}$ & $\begin{array}{l}R^{2}=0.02 \\
p=0.002\end{array}$ \\
\hline 4 & $\begin{array}{c}\text { Economic } \\
\text { Anxiety }\end{array}$ & $\mathrm{r}=0.380^{* * *}$ & $r=0.409^{* *}$ & $r=0.005$ & 1 & $\begin{array}{l}R^{2}=0.12 \\
p=0.000\end{array}$ \\
\hline 5 & $\begin{array}{c}\text { Sociopolitical } \\
\text { Impact }\end{array}$ & $r=0.267^{* *}$ & $r=0.329^{* *}$ & $\mathrm{r}=0.036$ & $\begin{array}{c}r= \\
0.304^{* * *}\end{array}$ & 1 \\
\hline \multicolumn{7}{|c|}{ Validity, Reliability and Normality Tests } \\
\hline \multicolumn{2}{|c|}{ Kaiser-Meyer-Olkin (KMO) } & \multicolumn{5}{|c|}{$0.867 / \mathrm{p}=0.000$} \\
\hline \multicolumn{2}{|c|}{$\begin{array}{l}\text { Cronbach alpha }(\alpha) \text { for sub- } \\
\text { dimensions }\end{array}$} & 0.843 & 0.805 & 0.789 & 0.761 & 0.526 \\
\hline \multicolumn{2}{|c|}{ Cronbach alpha $(\alpha)$ for the Scale } & \multicolumn{5}{|c|}{0.863} \\
\hline \multicolumn{2}{|c|}{ Shapiro-Wilk for Normality } & 0.000 & 0.000 & 0.000 & 0.000 & 0.000 \\
\hline \multirow{4}{*}{$\begin{array}{l}\text { Descriptive } \\
\text { Variables }\end{array}$} & Average & 38.3 & 14.4 & 17.1 & 14.6 & 18.7 \\
\hline & Standard deviation & 7.29 & 5.48 & 4.23 & 3.78 & 4.04 \\
\hline & Minimum & 10 & 6 & 5 & 4 & 6 \\
\hline & Maximum & 50 & 30 & 25 & 20 & 30 \\
\hline \multirow{6}{*}{$\begin{array}{l}\text { Personal and } \\
\text { Occupational } \\
\text { Variables }\end{array}$} & Age & 0.690 & 0.131 & $0.010^{*}$ & $0.001 * *$ & 0.498 \\
\hline & Gender & $0.001 * *$ & 0.072 & 0.302 & 0.378 & 0.538 \\
\hline & Marital Status & 0.310 & $0.043^{*}$ & 0.540 & 0.001 & 0.762 \\
\hline & Education Status & 0.710 & $0.010 *$ & $0.001 * *$ & $0.001 * *$ & $0.002 * *$ \\
\hline & $\begin{array}{l}\text { Employment } \\
\text { Status }\end{array}$ & 0.402 & 0.862 & $0.033^{*}$ & $0.007 * *$ & 0.328 \\
\hline & $\begin{array}{l}\text { Monthly Income } \\
\text { Status (TL) }\end{array}$ & $0.013^{*}$ & $0.006 * *$ & $0.031 *$ & $0.001 * *$ & 0.377 \\
\hline
\end{tabular}

$* \mathrm{p}<0.05 ; * * \mathrm{p}<0.01 ; \mathrm{r}=$ correlation coefficient; $\alpha=$ reliability coefficient 
According to the analysis results conducted in terms of personal and professional variables; there is a significant difference in terms of gender ( $\mathrm{p}=$ $0.001)$ and monthly income status $(\mathrm{p}=0.013)$ in the anxiety dimension. There is a significant difference in terms of marital status $(p=0.043)$, educational status $(p=$ $0.010)$ and monthly income status $(\mathrm{p}=0.006)$ in psychosocial the impact dimension. There is a significant difference in terms of age $(\mathrm{p}=0.010)$, educational status $(\mathrm{p}=$ $0.001)$, employment status $(p=0.033)$ and monthly income status $(p=0.031)$ in the trust dimension. There is a significant difference in terms of age $(p=0.001)$, educational status $(\mathrm{p}=0.001)$, employment status $(\mathrm{p}=0.007)$ and monthly income status $(\mathrm{p}=0.001)$ in the economic anxiety dimension. There is a significant difference in the sociopolitical impact dimension in terms of educational status ( $p$ $=0.001)$.

\section{Discussion}

In this study, it was aimed to measure the socio-psychological effects of the COVID-19 on Turkish people, and the scale was developed by the researchers. The draft scale preparing for developing a scale consisted of 40 items. Both EFA and CFA for the scale conducted. Nine items were eliminated from the draft scale. And the last version was created. The scale was named as "The COVID-19 Impact Assessment Scale." The scale was determined to be very good with a KMO value of 0.867 . Cronbach's Alpha $(\alpha)$ coefficient was found to be very good with 0.863 , and according to these results, it is seen that the scale has an adequate level of reliability.

Considering the findings obtained from the research; it was revealed that the participants obtained the most information about the COVID-19 from TV and then from internet news sites. In a study of COVID-19, participants indicated information sources like the internet with 93.5\% (Wang et al. 2020). The proportion of those who think that the process of fighting the COVID-19 in Turkey is better managed than in other countries is quite high $(64 \%)$. Very few (about $8 \%$ ) of the participants have a chronic disease. At least 22 million people have one or more chronic diseases, according to the Ministry of Health data (Ministry of Health of Turkey 2008). It can be said that the reason for this low rate in this study was the high number of young participants. The proportion of those diagnosed with COVID-19 for themselves or their acquaintances is very low $(2.5 \%)$. Nearly half of the respondents $(44.9 \%)$ believe that the progression of the COVID-19 will be controlled within a period from 1 month to 3 months.

When the studies on pandemic seen in the past years are examined, it was found in a study conducted on SARS disease in 2005 that $20 \%$ of the participants are concerned about their economic situation, and $27 \%$ have financial stress (Lau et al. 2005). In a study conducted on the Ebola pandemic by Van Bortel et al. (2016), it was found that the pandemic reduced economic efficiency and caused the social system to fail. In this study, it was observed that the sociopolitical impact dimension $(\mathrm{x}=18.7$; $\mathrm{sd}=4.04)$ was after the anxiety dimension $(\overline{\mathrm{x}}=38.3$; $\mathrm{sd}=7.29 ; 76.6 \%)$. In the comparative analysis in this study, it was found significant 
differences except for gender and marital status. It can be said that it is similar to other studies.

In another study conducted on COVID-19, 53.8\% of the respondents interpret the psychological effect of the pandemic as moderate or severe, one day after WHO declared the pandemic emergency (Wang et al. 2020). A similar study on H5N1 (avian flu) in 2007 shows that the public is not convinced that local authorities are well-prepared for the pandemic (Lau et al. 2007). In this study, the average of the sociopolitical effect dimension was found to be low when compared to other dimensions.

In 2006, in a study conducted on how the mental health of 549 employees who were exposed to the SARS epidemic of a hospital in Beijing was affected, it was found that $10 \%$ of the participants experienced a high level of post-traumatic stress since the SARS pandemic (Wu et al. 2009). Another study on the psychological state of 129 people quarantined because of the SARS pandemic in Canada found a high degree of psychological distress. It was observed posttraumatic stress disorder in $28.9 \%$ of these people, and depression symptoms in $31.2 \%$ of those (Hawryluck et al. 2004). In the study of the SARS pandemic, fear, loneliness, boredom, anger, and the fear of infecting the disease to the staff, family members, and friends were detected (Maunder et al. 2003). In this study, the average of psychosocial impact dimension was found at the lowest level when compared to other dimensions.

In a study conducted on the SARS outbreak, fear, loneliness, boredom, anger, and the fear of infecting the disease to the staff, family members, and friends were detected (Yücel and Görmez 2019). In another study conducted on SARS disease in 2005 , it was found that $36.3 \%$ of the participants felt emotionally disturbed because of SARS. $48.4 \%$ of whom think their mental health was serious and moderately deteriorated due to the SARS outbreak. $11.5 \%$ of the participants stated that they have difficulty falling asleep and sleeping comfortably for SARS-related thoughts. When the participants' situation before and during the SARS outbreak was compared, $4.2 \%$ of their family members were those who needed psychological and psychiatric services. $37.2 \%$ of whom reported that their social lives had become worse, and $20.1 \%$ reported difficulty concentrating on their work (Lau et al. 2005).

In a study conducted on the effects of the Ebola epidemic by Van Bortel et al. (2016), while the short-term effects of the epidemic in people were fear, anxiety, guilt, frustration, anger, and helplessness, the long-term effects were observed as trauma, mental health problems, along with witnessing the death of others. Fear, anxiety, isolation, mourning, social and cultural life were disrupted in the shortterm effects on the social level, and it was observed as loss of confidence and grief in the long-term effects. While the international short-term effects of the pandemic were fear, anxiety, and trauma, the long-term effects were observed as long-term mental health problems and discrimination. In this study, it was observed that the anxiety dimension $(\overline{\mathrm{x}}=38.3$; ss $=7.29 ; 76.6 \%)$ had the highest score. It can be said that this result supports the other study.

As a result of this study; multidisciplinary mental health teams (psychiatrists, psychiatric nurses, clinical psychologists, and other mental health workers) 
established should provide psychological support to reduce the anxiety level of patients and health workers at the regional and national levels. To deal with feelings of uncertainty and fear, clear communication should be provided regular and accurate updates about the COVID-19 to both healthcare professionals and patients. Both patients and their relatives should be provided with current information on treatment plans, progress reports, and health status. Low-income people must be supported, economically and fiscally. Policies should be developed in almost every field to increase the perceived level of trust even more.

\section{Limitations of the Study}

Since the research is prepared and distributed online, people who do not use the internet and cannot reach the web link of the survey are among the limitations of the research. Besides, research is limited to the date of 24.03 .2020 to 29.03.2020.

\section{References}

Albright JJ, Park HM (2009) Confirmatory factor analysis using Amos, Lisrel, Mplus, and SAS/STAT CALIS. Working paper. USA: The University Information Technology Services (UITS) Center for Statistical and Mathematical Computing, Indiana University.

Brooks SK, Webster RK, Smith LE, Woodland L, Wessely S, Greenberg N et al. (2020) The psychological impact of quarantine and how to reduce it: rapid review of the evidence. The Lancet 395(10227): 912-920.

Centers for Disease Control and Prevention (2020a) Coping with stress. Retrieved from: https://www.cdc.gov/coronavirus/2019-ncov/prepare/managing-stress-anxiety.html. [Accessed 1 July 2020]

Centers for Disease Control and Prevention (2020b) 1918 pandemic (HIN1 virus). Retrieved from: https://www.cdc.gov/flu/pandemic-resources/1918-pandemic-h1n1. html. [Accessed 20 June 2020]

De Roo A, Ado B, Rose B, Guimard Y, Fonck K, Colebunders R (1998) Survey among survivors of the 1995 Ebola epidemic in Kikwit, democratic republic of Congo: their feelings and experiences. Tropical Medicine \& International Health 3(11): 883-885.

Field A (2002) Discovering statistics using IBM SPSS statistics. London: Sage Publications Ltd.

Funk S, Gilad E, Watkins C, Jansen VAA (2009) The spread of awareness and its impact on epidemic outbreaks. Proceedings of the National Academy of Sciences of the United States of America 106(16): 6872-6877.

Hall RCW, Chapman MJ (2008) The 1995 Kikwit Ebola outbreak: lessons hospitals and physicians can apply to future viral epidemics. General Hospital Psychiatry 30(5): 446-452.

Hawryluck L, Gold WL, Robinson S, Pogorski S, Galea S, Styra R (2004) SARS control and psychological effects of quarantine, Toronto, Canada. Emerging Infectious Diseases 10(7): 1206-1212.

Kagan D, Moran-Gilad J, Fire M (2020) Scientometric trends for coronaviruses and other emerging viral infections. GigaScience 9(8): 1-17. 
Karakoç FY, Dönmez L (2014) Basic principles of scale development. Tıp Eğitimi Dünyası 13(40): 39-49.

Karagöz Y (2016) SPSS 23 ve AMOS 23 uygulamal istatistiksel analizler. (SPSS and AMOS applied statistical applications). Turkey: Nobel Yayınevi.

Lau JT, Yang X, Pang E, Tsui H, Wong E, Wing Y (2005) SARS-related perceptions in Hong Kong. Emerging Infectious Diseases 11(3): 417-424.

Lau JT, Kim JH, Tsui H, Griffiths S (2007) Perceptions related to human avian influenza and their associations with anticipated psychological and behavioral responses at the onset of outbreak in the Hong Kong Chinese general population. American Journal of Infection Control 35(1): 38-49.

Majumder P, Biswas P, Majumder S (2020) Application of new TOPSIS approach to identify the most significant risk factor and continuous monitoring of death of COVID-19. Electronic Journal of General Medicine 17(6): em234.

Maunder R, Hunter J, Vincent L, Bennett J, Peladeau N, Leszcz M et al. (2003) The immediate psychological and occupational impact of the 2003 SARS outbreak in a teaching hospital. Canadian Medical Association Journal 168(10): 1245-1251.

Musinguzi G, Asamoah BO (2020) The science of social distancing and total lock down: Does it work? Whom does it benefit? Electronic Journal of General Medicine 17(6): em230.

Nancy AT, Christopher VGD (2007) Healthcare executives' role in preparing for the pandemic influenza "gap": a new paradigm for disaster planning? Journal of Healthcare Management 52(2): 87-94.

Oxford Analytica (2020) COVID-19, May 14. Retrieved from: https://www.oxan.com/ media/2854/covid-19_oxfordanalytica_2020-05-14.pdf. [Accessed 15 June 2020]

Şanlı K (2010) İnfluenza virüsü ve domuz gribi. (Influenza virus and swine influenza). Jinekoloji Obstretrik Pediatri Dergisi 2(1): 4-12.

Sirman A (2020) Tarih boyunca salgınlar ve COVID-19. (Outbreaks throughout history and COVID-19). Populer Science 96(4): 36-47.

Temel MK (2015) Gelmiş geçmiş en büyük katil: 1918 "ispanyol" gribi. (The biggest killer ever: the "Spanish" flu of 1918). Turkey: Betim Yayın.

Ministry of Health of Turkey (2008) T.C. Sa ğllk Bakanlı̆̆. kronik hastaliklar risk faktörleri sağliğin teşviki ve geliştirilmesi sempozyumu. (Noncommunicable diseases risk factors and health promotion symposium). Ankara: Ministry of Health of Turkey.

Turkish Labor Law (No: 4857) Regulation on the principles and procedures for the employment of children and young persons. Turkey.

Turkish Statistical Institute (2019) The results of address-based population registration system. Retrieved from: http://www.turkstat.gov.tr/HbGetirHTML.do?id=33705. [Accessed 1 June 2020]

Van Bortel T, Basnayake A, Wurie F, Jambai M, Koroma AS, Muana AT et al. (2016) Psychosocial effects of an Ebola outbreak at individual, community and international levels. Bulletin of the World Health Organization 94(3): 210-214.

Wang C, Pan R, Wan X, Tan Y, Xu L, Ho DS et al. (2020). Immediate psychological responses and associated factors during the initial stage of the 2019 coronavirus disease (COVID-19) epidemic among the general population in china. International Journal of Environmental Research and Public Health 17(5): 2-25.

World Health Organization (2019) Middle east respiratory syndrome coronavirus (MERSCoV). Retrieved from: https://www.who.int/emergencies/mers-cov/en/. [Accessed 25 May 2020]

World Health Organization (2020) Coronavirus disease (COVID-19): weekly epidemiological update. Retrieved from: https://www.who.int/docs/default-source/coronaviruse/situ 
ation-reports/20200907-weekly-epi-update-4.pdf?sfvrsn=f5f607ee_2. [Accessed 6 September 2020]

Wu P, Fang Y, Guan Z, Fan B, Kong J, Yao Z et al. (2009) The psychological impact of the SARS epidemic on hospital employees in China: exposure, risk perception, and altruistic acceptance of risk. Canadian Journal of Psychiatry 54(5): 302-311.

Xiang Y-T, Yang Y, Li W, Zhang L, Zhang Q, Cheung TH et al. (2020) Timely mental health care for the 2019 novel coronavirus outbreak is urgently needed. Lancet Psychiatry 7(3): 228-229.

Yazıcıoğlu Y, Erdoğan S (2004) SPSS uygulamalı bilimsel araştırma yöntemleri. (SPSS applied scientific research methods). Turkey: Detay Yayıncilık

Yücel B, Görmez A (2019) SARS-Corona virus overview. Turkish Journal of Applied Sciences and Technology 2(1): 32-39.

Zaki AM, van Boheemen S, Bestebroer TM, Osterhaus AD, Fouchier RA. (2012) Isolation of a novel coronavirus from a man with pneumonia in Saudi Arabia. The New England Journal of Medicine 367(19): 1814-1820. 


\begin{tabular}{|c|c|}
\hline No & Items \\
\hline 1 & I have information about the COVID-19. \\
\hline 2 & Even hearing the name of the COVID-19 bothers me. \\
\hline 3 & The health problems that may occur with the COVID-19 cause concern in me. \\
\hline 4 & I have had sleep problems since I heard the name of the COVID-19. \\
\hline 5 & I generally feel uneasy since the COVID-19 started in our country. \\
\hline 6 & Since the COVID-19 was seen in our country, I have isolated myself, socially. \\
\hline 7 & I have a fear of death because of the COVID-19. \\
\hline 8 & I am having trouble eating because of the fear of death in the COVID-19. \\
\hline 9 & Even the thought of getting sick because of the COVID-19 worries me. \\
\hline 10 & The COVID-19 worries me because of the fear of transmitting the disease to others. \\
\hline 11 & The COVID-19 worries me as it is an uncertain situation. \\
\hline 12 & The COVID-19 worries me as it's a new situation. \\
\hline 13 & $\begin{array}{l}\text { Since the COVID-19 and deaths appeared in our country, I have difficulty in collect my } \\
\text { attention. }\end{array}$ \\
\hline 14 & $\begin{array}{l}\text { I have been more angry and nervous since the COVID-19 and deaths appeared in our } \\
\text { country. }\end{array}$ \\
\hline 15 & $\begin{array}{l}\text { Since the COVID-19 and deaths appeared in our country, problems in my "family life" } \\
\text { have increased. }\end{array}$ \\
\hline 16 & $\begin{array}{l}\text { Since the COVID-19 and deaths appeared in our country, problems in my business life } \\
\text { have increased. }\end{array}$ \\
\hline 17 & $\begin{array}{l}\text { Since the COVID-19 and deaths appeared in our country, problems in my social } \\
\text { environment have increased. }\end{array}$ \\
\hline 18 & I can easily say "no" to those who want to meet from my social circle. \\
\hline 19 & I would be concerned that even if this pandemic is over, there could still be a disease. \\
\hline 20 & I think traditional treatment methods work in the fight against the COVID-19. \\
\hline 21 & I don't think modern drugs influence the COVID-19. \\
\hline 22 & Health facilities in our country have sufficient infrastructure to combat the COVID-19. \\
\hline 23 & City hospitals will assume an important burden in the fight against the COVID-19. \\
\hline 24 & Healthcare professionals work devotedly to the fight against the COVID-19. \\
\hline 25 & News of the media organs about the COVID-19 is informative. \\
\hline 26 & The posts about the COVID-19 in social media are insufficient. \\
\hline 27 & $\begin{array}{l}\text { Problems or deficiencies that may arise in the fight against the COVID-19 can be a } \\
\text { political material. }\end{array}$ \\
\hline 28 & When developed the vaccine for the COVID-19, I would not hesitate to get vaccinated. \\
\hline 29 & I believe that the COVID-19 process is transparently conducted. \\
\hline 30 & I don't think hospitals will need medical staff. \\
\hline 31 & My economic situation affected because of the COVID-19, negatively. \\
\hline 32 & I think the COVID-19 will negatively affect the country's economy. \\
\hline 33 & Economic anxiety affects me as much as sickness anxiety. \\
\hline 34 & $\begin{array}{l}\text { Even the possibility of an economic crisis because of the COVID-19 worries about } \\
\text { losing my job. }\end{array}$ \\
\hline 35 & Even if I take my precaution, it makes me uneasy that one of my family goes out. \\
\hline 36 & I think the level of social impact is low in the spread of the COVID-19. \\
\hline 37 & I think the COVID-19 is a biological weapon. \\
\hline 38 & $\begin{array}{l}\text { I have enough information about what treatment process will be applied after catching } \\
\text { the COVID-19. }\end{array}$ \\
\hline 39 & People's responsibilities are insufficient to prevent the spread of the COVID-19. \\
\hline 40 & I think that the health policies on the COVID-19 are sufficient. \\
\hline
\end{tabular}

Note: Items 1, 5, 7, 13, 20, 24, 28, 30, and 38 were removed from the scale after conducted exploratory factor analysis. 
